\title{
Separation of Y-chromosome Bearing Ram's Sperms using an Albumin Gradient Technique and Identification of Embryos by PCR
}

\author{
S. Hadi \\ I. H. Al-Timimi \\ Coll. of Vet. Med./ Unive. of Baghdad
}

\begin{abstract}
Several advantages have been suggested for producing sexed sperms including using fewer and genetically superior female animals for replacement.Four hundred active ovaries collected from the slaughter house of Al-shu'alah, the number and type of oocytes, ratios of maturation and fertilization shown that there was a significant difference in the numbers of oocytes $(\mathrm{P}<0.05)$ between right and left ovaries. A high recovery rate was obtained of good oocyte (Grade A) $42.35 \%$ (432/1020), fair oocyte (Grade B) 37.54\% (383/1020) followed by and poor oocyte (Grade C) $17.84 \%(182 / 1020)$. There was a significant difference $(\mathrm{P}<0.05)$ between the 3 different grades. grades A and B oocytes, (815/1020) 79.9\% of recovered oocytes were cultured. Maturation rate was $86.38 \%$ (704/815).Y- Bearing sperms separation applied by using procedure of the modified albumin technique; either one $(8 \%)$ or two layers (8 and $16 \%)$ of BSA $\left(\mathrm{M}_{1}\right.$, and $\mathrm{M}_{2}$ ) at 200,300 or $400 \mathrm{xg}$, then used for in vitro fertilization. The in vitro fertilization rate observed was $21.8 \%$ (132/604) of matured oocytes by choosing universal primers from sequences that are highly conserved in the $\mathrm{X}$ and $\mathrm{Y}$ chromosomes, sex-specific sequences were successfully amplified in embryonic lysates. Bovine serum albumin sexed sperms result in more percentage of male embryos by using one layer of BSA $(8 \%)$ at $200 \times \mathrm{g}\left(\mathrm{M}_{1 \mathrm{a}}\right)$ and $300 \times \mathrm{g}\left(\mathrm{M}_{1 \mathrm{~b}}\right)$ which were $72.7 \%$ and $54.5 \%$ respectively, and shows a deviation $(\mathrm{p}<0.05)$ from the $50 \%$ expected percentage for male and female embryos. While using two layer of BSA (16\% and 8\% BSA) at the $200 \times \mathrm{g}\left(\mathrm{M}_{2 \mathrm{a}}\right)$ and at $300 \times \mathrm{g}\left(\mathrm{M}_{2 \mathrm{~b}}\right)$ were $81.8 \%$ and $63.6 \%$ respectively. When we compare the rate of male embryos produced from IVF by sperms isolated by two layers of BSA $\left(\mathrm{M}_{2 \mathrm{a}}\right.$, and $\left.\mathrm{M}_{2 \mathrm{~b}}\right)$, moderate results obtained with $\mathrm{M}_{2 \mathrm{~b}}(63.6 \%)$ while the best results were with $\mathrm{M}_{2 \mathrm{a}}$ separation protocol $(81.8 \%)$.
\end{abstract}

\section{Introduction}

Sexing of ovine sperms might affect both biological and economical effectiveness. Several advantages have been suggested for producing sexed sperms including using fewer and genetically superior dairy females for heifer replacement (1), to provide a wider chance for crossbreeding dairy females, fewer numbers of them required for progeny testing (2), and to facilitate endangered species conservation (1).A great concern and debate on sexselection has resulted when discontinuous albumin gradient technique was used to enrich the Y-chromosome bearing sperms in human (3). Since then, many new techniques have been developed to separate spermatozoa, such as modified swim-up procedure to enrich $\mathrm{Y}$-chromosome bearing sperms(4), Sephadex column technique and 12-step Percoll gradients to enrich X-bearing sperms (5and6) and free-flow electrophoresis (7and8). However, the validation of the enrichment of $\mathrm{X}$ - and $\mathrm{Y}$ chromosome is controversial. It has been suggested that, flow cytometry to separate the sperms showed a promising commercial potential to sex sperms (9,10and11). Unfortunately, this technique requires appropriate skills and expertise as well as it is not easily accessible. The objective of this study was to evaluate the effectiveness of an albumin gradient technique in separating the ram sperms carrying Y-chromosomes. 


\section{Materials and Methods}

\section{Oocytes collection from slaughterhouse ewe:-}

Female genitalia $(n=400)$ of local ewes were collected from Al-shu'alah abattoir. The reproductive history of the animals was unknown. Genetalia were transported within one hour in a normal saline in cool box to the Laboratory. The ovaries were removed from the surrounding tissue and over lying bursa washing in normal saline and two washings in collecting media (Modified Tyrodes Albumin Lactate Pyruvate Media (m TALP).The follicles were counted and their diameters were measured with an automatic vernier. Oocytes were collected by aspiration from 4-8 $\mathrm{mm}$ size follicles.The media with harvested oocytes were transferred to one well out of 24 wells dish after grading to good, fair, and poor (type A, B, C).

\section{In vitro Maturation:-}

Only good and fair classified oocytes were selected. The oocytes were washed twice in a maturation medium (TALP), incubated in appropriate maturation medium at $39{ }^{\circ} \mathrm{C}$ temp, $5 \% \mathrm{CO}_{2}$ and $90 \%$ relative humidity for $27 \mathrm{hrs}$. The presence of the first polar body was a good criterion for maturation of oocytes in vitro (IVM).

\section{Semen collection:-}

Three local rams of proven fertility used in this experiment, presented in the farm of College of Agriculture, Baghdad University, fresh semen was collected by artificial vagina (AV). Ejaculates from rams were pooled in equal quantities for final volume of $1-1.5 \mathrm{ml}$ in order to minimize the variation between rams.Semen sample were examined under light microscope. The mass and individual motility was assessed, samples which showed less than $60 \%$ progressive motility was rejected.

Modified procedures of the albumin separation method $\left(M_{1 a}, M_{1 b}, M_{2 a}\right.$, and $\mathbf{M}_{2 \mathrm{~b}}$ ):-

The procedure of the modified albumin technique followed in this study is basically the same as the one described by the Beernink et al. (1993) (12) with minor modifications. The Modified albumins separating $\mathrm{X}$ and $\mathrm{Y}$ chromosome bearing sperms technique involves the following steps:-

Pooled semen was diluted 1:1 with Hepe's Buffer Hank's Solution and centrifuged for 10 minutes at $200 \times \mathrm{g}$. The supernatant was removed and the pellet was re suspended with $0.5 \mathrm{ml}$ Hepe's Buffer Hank's Solution (concentration 3.22-3.97 $\left.\times 10^{9} \mathrm{sperm} / \mathrm{sample}\right)$. In this procedure, we used the following protocols:-

Protocol 1 (200 $\times$ g- $\left.\mathbf{M}_{1 \mathrm{a}}, 300 \times \mathrm{g}-\mathrm{M}_{1 \mathrm{~b}}\right)$, (using one layer of BSA):-

Test tubes (six tubes) containing $0.5 \mathrm{ml}$ of washed semen sample was layered over 1 $\mathrm{ml}$ of $8 \%$ bovine serum albumin (BSA) (Merk, Germany), incubated for $1 \mathrm{hr}$ at room temperature. At the end of the incubation period, the upper layers discarded, the lower layers of each column were pooled and diluted with Hepe's Buffer Hank's Solution $1: 1$, centrifuged for $10 \mathrm{~min}$ at $200 \times \mathrm{g}, 300 \times \mathrm{g}$ or $400 \times \mathrm{g}$, the supernatant was discarded, and each pellet was re suspended in $0.25-0.5 \mathrm{ml}$ of Hepe's Buffer Hank's Solution, then sperms analysis was applied.

Protocol 2 (200×g $\left.M_{2 a}, 300 \times g M_{2 b}\right)$, (using 2 layers of BSA):-

Test tubes (six tubes) containing $0.5 \mathrm{ml}$ of washed sperms was layered over 2 layers of BSA; $1 \mathrm{ml}$ of $8 \%$ BSA over $0.5 \mathrm{ml}$ of $16 \% \mathrm{BSA}$, incubated at room temperature. After 60min, the sperm suspension and upper half of the $8 \% \mathrm{BSA}$ layer were removed. After further $30 \mathrm{~min}$, the remained $0.5 \mathrm{ml}$ of the $8 \%$ BSA layer and upper part of the $16 \%$ BSA layer were removed. The remainder of the $16 \%$ BSA layers was pooled in a test tube, diluted with Hepe's Buffer Hank's Solution 1:1, centrifuged for $10 \mathrm{~min}$. at $(200 \times \mathrm{g}, 300 \times \mathrm{g}$ or $400 \times \mathrm{g})$. The supernatant was removed and the final sperm pellet was re suspended in $0.25-0.5 \mathrm{ml}$ 
of Hepe's Buffer Hank's Solution prior to sperm analysis.

\section{Capacitating of sperms:-}

Selected sperm samples were dilution 1:10 with TALP, then diluted 1:1 with heparin chloride containing media $(100 \mu \mathrm{g} / \mathrm{ml})$ and incubated for 45 minutes at $38{ }^{\circ} \mathrm{C}$ according to the procedure of Palamo et al.,(13).

\section{In vitro fertilization:-}

Capacitated sperms suspension were diluted to yield a final concentration of 1.0 $\mathrm{x} 10^{6} \mathrm{sperm} / \mathrm{ml}$ in the fertilization medium (TALP), pH 7.4-7.8. Only matured oocytes were kept in group of 5 to 10 oocytes in one well of 24 wells petridish containing fertilization medium with sperms and incubated at $39^{\circ} \mathrm{C}, 5 \% \mathrm{CO}_{2}$ and $90 \%$ relative humidity for $27 \mathrm{hr}$ (14).

\section{Evaluation of fertilized oocytes:-}

Twenty seven hrs after fertilization, oocytes having $2^{\text {nd }}$ polar body or oocyte with sperm head in the cytoplasm were evaluated as fertilized oocyte. The numbers of fertilized oocytes were counted.

\section{In vitro Culture:-}

Cultures of previously fertilized oocytes (zygotes) were performed. Embryos were cultured in (TALP) at 38.5$39{ }^{\circ} \mathrm{C}, 5 \% \quad \mathrm{CO}_{2}$, and $90 \%$ humidity. Embryonic developments were observed every $24 \mathrm{hrs}$ and $50 \%$ of the media volume was replaced with fresh one at $24 \mathrm{hrs}$ intervals. According to Keskintepe et al., (15) procedure, ova that did not show cleavage were removed from the wells at the time of each change of medium. Proportions of fertilized oocytes reached 4 cells stage were recorded, and then extraction of DNA from embryos was applied.

\section{DNA extraction from Embryos:-}

The cultured embryos were washed twice in culture medium and three times in $\mathrm{KCl}$ medium with $2 \mathrm{~g} / \mathrm{L}$ bovine serum albumin. DNA was isolated from the embryos by the single step method described by Taneja et al. (16) in a $1 \times$ PCR buffer $(10 \mathrm{mM}$ Tris $\mathrm{HCl}, \mathrm{pH} 8.3$, $50 \mathrm{mM} \mathrm{KCl}, 1.5 \mathrm{mM} \mathrm{MgCl} 2$ and $0.01 \%$ gelatin) containing Proteinase-K (150 $\mu \mathrm{g} / \mathrm{ml}$ ) and incubated for $1 \mathrm{hr}$ at $37^{\circ} \mathrm{C}$. Then Proteinase- $\mathrm{K}$ was inactivated by incubating at $99^{\circ} \mathrm{C}$ for $10 \mathrm{~min}$. The tubes were kept frozen at $-20^{\circ} \mathrm{C}$ until sexing was carried out by PCR.

\section{Polymers Chain Reaction (PCR)} Technique:-

Identification of DNA was performed in $20 \mu 1$ reactions containing approximately $5 \mathrm{ng}$ of template DNA isolated from embryo, 5 pmole primer(Promiga, Germany), and $250 \mu \mathrm{M}$ each: dNTP (dATP, dCTP, dGTP, and dTTP), 1U Taq DNA polymerase, $10 \mathrm{mM}$ Tris-HCL (pH 9.0), 30mM KCL and 1.5 $\mathrm{mM} \mathrm{MgCL}$. (Bio Neer, Kory).The PCR amplification was carried out using a "MJ research thermal cycler" with the following amplification procedure: An initial denaturation for $5 \mathrm{~min}$ at $95^{\circ} \mathrm{C}$ was followed by 40 cycles of denaturation $(60$ $\mathrm{sec}$ at $94^{\circ} \mathrm{C}$ ), primer annealing (for $60 \mathrm{sec}$ at $56^{\circ} \mathrm{C}$ ) and strand synthesis (for $120 \mathrm{sec}$ at $72^{\circ} \mathrm{C}$ ), and in the last cycle, the samples were held at $72^{\circ} \mathrm{C}$ for an additional $5 \mathrm{~min}$. The amplification was confirmed by agarose gel electrophoresis $(1 \%)$, stained with $2.5 \mu \mathrm{l}$ ethidium bromide and visualized under UV light (260-280nm).

\section{Restriction enzyme analysis:-}

PCR products (15 $\mu$ l each) were subjected to digestion at $37^{\circ} \mathrm{C}$ for $3 \mathrm{~h}$ with 20 units of Sac I (Promiga, Germany). The Restriction fragment length polymorphism (RFLP) was then analyzed using $2.5 \%$ agarose gel electrophoresis and visualized under UV light (260-280nm).

\section{Results and Discussion}

Oocytes collection, maturation and fertilization:-
Four hundred of active ovaries collected from the slaughter house, the number and type of oocytes, ratios of 


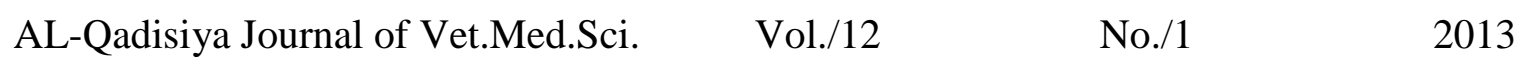

maturation and fertilization were recorded. There was a significant difference in the numbers of oocytes $(\mathrm{P}<0.05)$ of right and left ovaries. Similar observations have been revealed by several investigators $(17,18$, and 19).

\section{Grading of oocytes:-}

Visual assessment of morphological features is the most important vehicle for selection of oocytes before maturation during oocytes recovery.Our results showed that a high recovery rate was obtained of good oocytes (Grade A) 42.35\% (432/1020), fair oocytes (Grade B) 37.54\% (383/1020) followed by and poor oocytes (Grade C) $17.84 \%(182 / 1020)$. There was a significant difference $(\mathrm{P}<0.05)$ between the 3 different grades.Same observations have been reported by Wani et al., (20) in sheep and by Sogorescu et al. (21) in sheep and goats. The ability to identify good quality oocytes prior to in vitro culture is as important consideration for IVP of embryo system.Embryo development is influenced by events occurring during oocyte maturation, so for successful IVM, oocytes must undergo nuclear and cytoplasmic maturation. Only grades A and B oocytes, $(815 / 1020) 79.9 \%$ of recovered oocytes were cultured. Maturation rate was $86.38 \%$ (704/815). Our results were similar observations which had been reported by other workers $(22,23$, and 24). It is obvious that oocyte quality is essential for embryonic development. The ability to identify good quality oocytes prior to in vitro culture is as important consideration for IVP of embryo system (24 and 25). The in vitro fertilization rate observed was $21.8 \% \quad(132 / 604)$ of matured oocytes. The percentage of fertilization was low compared with the results reported by Sogorescu et al. (21), Khatun et al. (26) and by Hoque et al. (27). The fertilization rate obtained from slaughter house samples could be affected by several factors playing a role in successful IVF like cultural media, semen preparation with capacitating agents, season, follicle size and oocyte collection techniques.

\section{Identification of sex of the embryo by PCR:-}

PCR technique has been applied for the identification of sex of embryos with WBC obtained from male and female sheep as follow:-

By choosing universal primers from sequences that are highly conserved in the $\mathrm{X}$ and Y chromosomes, sex-specific sequences were successfully amplified in embryonic lysates. The embryos subjected to PCR with "universal primer" showed uniform banding patterns (447 bp) irrespective of sex (Figure 1). This technique has recently been used as a reliable technique for the quantification of $\mathrm{X}$ and $\mathrm{Y}$ sperm cells in semen samples, especially to validate techniques for sexing sperm $(28,29$, and 30).

Using sperms selected by modified bovine serum albumin gradient technique $\left(M_{1 a}\right.$, $\mathbf{M}_{1 \mathrm{~b}}, \mathbf{M}_{2 \mathrm{a}}$, and $\mathbf{M}_{2 \mathrm{~b}}$ ):-

Bovine serum albumin sexed sperms result in more percentage of male embryos by using one layer of BSA $(8 \%)$ at $200 \times \mathrm{g}$ $\left(\mathrm{M}_{1 \mathrm{a}}\right)$ and $300 \times \mathrm{g}\left(\mathrm{M}_{1 \mathrm{~b}}\right)$ which were $72.7 \%$ and $54.5 \%$ respectively, and shows a deviation $(\mathrm{p}<0.05)$ from the $50 \%$ expected percentage for male and female embryos. While using two layer of BSA (16\% and $8 \%$ $\mathrm{BSA})$ at the $200 \times \mathrm{g}\left(\mathrm{M}_{2 \mathrm{a}}\right)$ and at $300 \times \mathrm{g}$ $\left(\mathrm{M}_{2 \mathrm{~b}}\right) \quad$ were $81.8 \%$ and $63.6 \%$ respectively.Corson et al., (1984) (31) using the albumin separation technique, reported that 28 males were born out of 35 conceptions $(80 \%)$. Also male-birth ratio of $73.5 \%$ using a three-layer separation was reported by Beernik and Ericsson, (1982) (32), the two-step, two-layer separation technique was reported to produce a male birth ratio of $73 \%$.Ericsson et al., (3) reported separation of $\mathrm{X}$ - from Y-bearing sperm by placing a solution of sperm on a layer of BSA. Apparently, Y-bearing sperm moved more quickly into the albumin. The researches hypothesize that Y-bearing sperm swim faster in BSA than $\mathrm{X}$ - bearing sperm. 


\section{$\begin{array}{llll}\text { AL-Qadisiya Journal of Vet.Med.Sci. } & \text { Vol./12 No./1 }\end{array}$}

From our results we can conclude that the purity of selected Y-sperms and the percentage of male embryos obtained by IVF were good when we use $\mathrm{M}_{2 \mathrm{a}, 2 \mathrm{~b}}$ than $\mathrm{M}_{1 \mathrm{a}}, \quad 1 \mathrm{~b}$ protocols. The only difference showing lowest rate of male embryos $(54.5$ $\%$ ) was observed in one layer of BSA $\left(\mathrm{M}_{1 \mathrm{~b}}\right)$. This might be due to low concentrations of
BSA, low number of layer and speed of centrifugation used.Also, when we compare the rate of male embryos produced from IVF by sperms isolated by two layers of BSA $\left(\mathrm{M}_{2 \mathrm{a}}\right.$, and $\left.\mathrm{M}_{2 \mathrm{~b}}\right)$, the a moderate results obtained with $\mathrm{M}_{2 \mathrm{~b}}(63.6 \%)$ while the best results were with $\mathrm{M}_{2 \mathrm{a}}$ separation protocol $(81.8 \%)$, results shown in table (1).

Table1:- Percentage of male and female embryos obtained after separation by albumin gradient technique compared with the expected percentage of $50 \%$ of each gender and between treatments.

\begin{tabular}{|l|c|c|c|c|c|}
\hline \multirow{2}{*}{ Treatment } & \multirow{2}{*}{$\begin{array}{c}\text { No of } \\
\text { embryos }\end{array}$} & \multicolumn{2}{|c|}{ Male } & \multicolumn{2}{c|}{ Female } \\
\cline { 3 - 6 } & 11 & 8 & $(72.70)$ & 3 & $(27.20)$ \\
\hline M1a & 11 & 6 & $(54.50)$ & 5 & $(45.40)$ \\
\hline M1b & 11 & 9 & $(81.80)$ & 2 & $(18.10)$ \\
\hline M2a & 11 & 7 & $(63.60)$ & 4 & $(36.30)$ \\
\hline M2b & &
\end{tabular}

M1a:-BSA one layer 200xg, M1b:-BSA one layer 300xg, M2a:-BSA two layer 200xg, M2b:-BSA two layer 300xg.

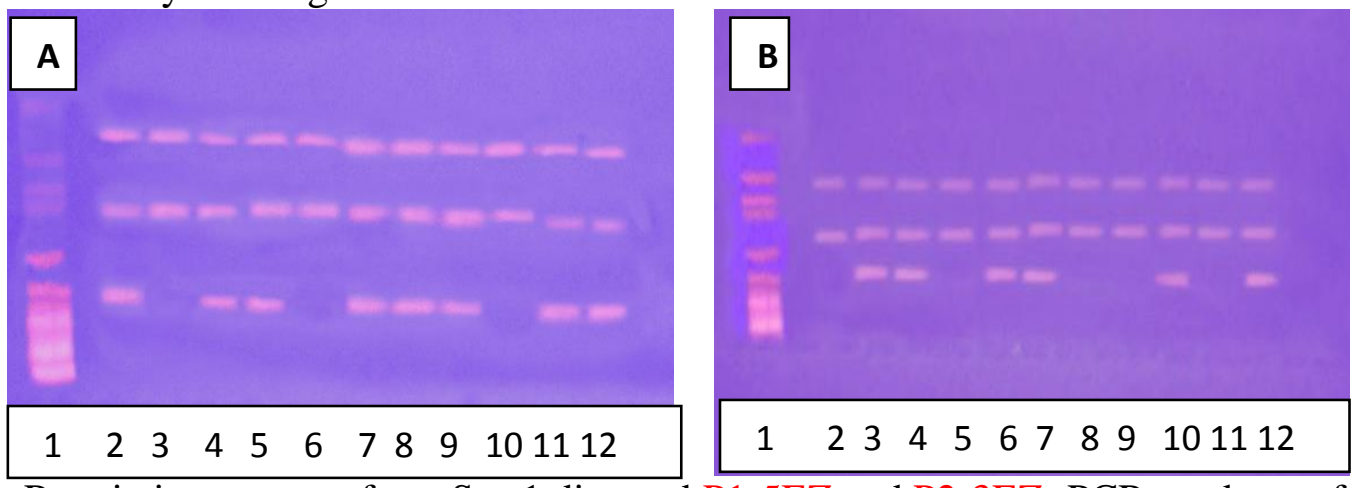

Figure 1: Restriction patterns from Sac 1 digested P1-5EZ and P2-3EZ- PCR products of sheep embryos Lane1: 100 bp ladder (marker).

a- Sexed embryos at $\mathrm{M}_{1 \mathrm{a}}$ : Female lanes 3, 10 and 6 only. Male lanes 2, 4, 5, 7, 8, 9, 11 and 12.

b- Sexed embryos at $\mathbf{M}_{1 \mathrm{~b}}$ : Female lanes 2, 5, 8, 9 and 11 only. Male lanes 3, 4, 6, 7, 10 and 12.
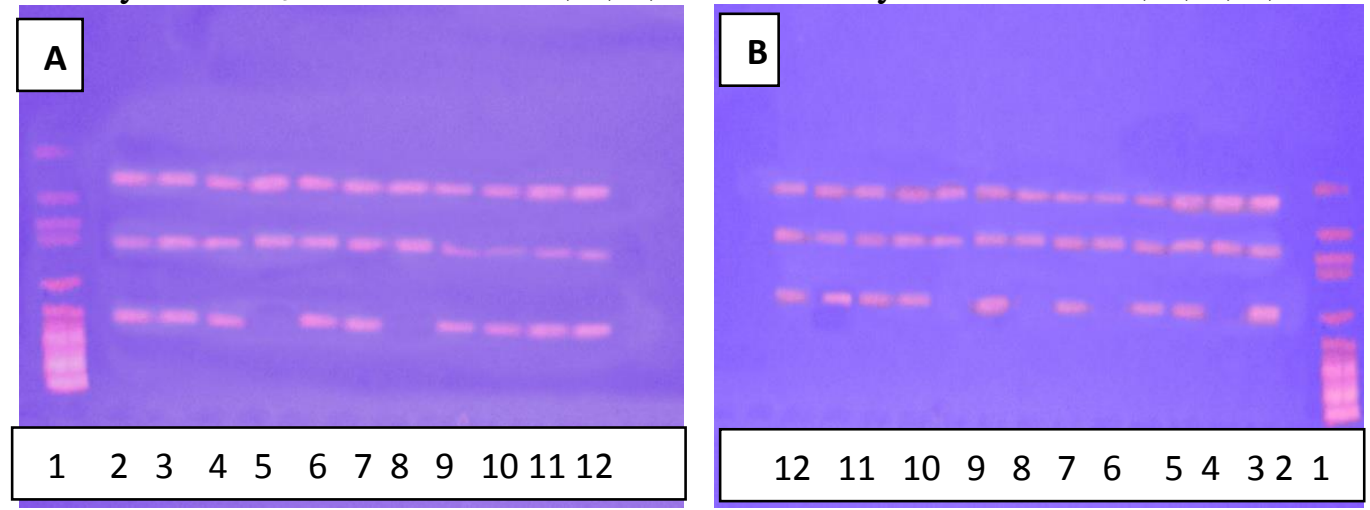

Figure 2: Restriction patterns from Sac 1 digested P1-5EZ and P2-3EZ- PCR products of sheep embryos Lane1: 100 bp ladder (marker).

a- Sexed embryos at $\mathrm{M}_{2 \mathrm{a}}$ : Female lanes 5, and 8 only. Male lanes 2, 3, 4, 6, 7, 8, 10, 11 and 12.

b- Sexed embryos at $\mathbf{M}_{2 \mathrm{~b}}$ : Female lanes 3, 6, 8 and 10 only. Male lanes 2, 4, 5, 7, 9, 11 and 12. 


\section{References}

1. Prasad, S., Rangasamy, S. and Satheshkumar, S. 2010. Sex preselection in domestic animals Current status and future prospects. Vet. World 3(7): 346-348.

2. Hohenboken, W.D. 1999. Applications of sexed semen in cattle production. Theriogenology 52: 1421-1433.

3. Ericsson, R.J., Langevin, C.N. and Nishino, M. 1973. Isolation of fractions rich in human $\mathrm{Y}$ sperm. Nature 246: 421-424.

4. Check, J.H. and Katsoff, D. 1993. A prospective study to evaluate the efficacy of modified swim-up preparation for male sex selection. Hum. Reprod. 8: 211-214.

5. Steeno, O., Adimoelja, A. and Steeno, J. 1975. Separation of $X^{-}$and $Y$ bearing human spermswith the Sephadex gel-filtration method. Andrologia 7: 95-97.

6. Iizuka, R., Kaneko, S., Aoki, R. and Kobasyahi, T. 1987. Sexing of human sperm discontinuos Percoll density gradient and its clinical application. Hum. Reprod. 2: 573575.

7. Blottner, S., Bostedt, H., Mewes, K. and Pitra, C. 1994. Enrichment of bovine $\mathrm{X}$ and $\mathrm{Y}$ spermsby free-flow electrophoresis. J. Vet. Med. Series A 41(1-10): 466-474.

8. Ainsworth, C., Nixon, B., Jansen, R.P.S. and Aitken, R.J. 2007. First recorded pregnancy and normal birth after ICSI using electrophoretically isolated spermatozoa. Hum Reprod. 22: 197-200.

9. Garner, D.L., Gledhill, B.L., Pinkel, D., Lake, S., Stephenson, D., Van Dilla, M.A. and Johnson, L.A. 1983. Quantification of the X- and Y-chromosome bearing spermsof domestic animals by flow cytometry. Biol. Reprod. 28: 312.
10. Welch, G.R. and Johnson, L.A. 1999.

Sex pre-selection: laboratory validation of the sperm sex ratio of flow sorted $\mathrm{X}$ - and $\mathrm{Y}$-sperm by sort reanalysis for DNA. Theriogenology 52: 1343-1352.

11. Seidel, G.E. and Gardner, D.L. 2002. Current status of sexing spermatozoa. Hum. Reprod. 124(6): 733-743.

12. Beernink, F.J., Dmowski, W.P. and Ericsson, R.J. (1993) Sex preselection albumin separation of sperm. Fertil. Steril., 59, 382-386.

13. Palamo M J Izquierdo D Mogas $T$ and Paramio M T (1999). Effect of semen preparation on IVF of prepubertal goat oocytes. Theriogenology, 51: 927- 940.

14. Kharche S D Goel P Jha B K Goel A K and Jindal S K (2011). Factors influencing in vitro embryo production efficiency caprine oocytes: A review. Indian J. Anim. Sci., 81 (4): 344- 361.

15. Keskintepe L Simplicio A and Brackett B G (1998). Caprine blastocyst development after in vitro fertilization with sperms frozen in different extenders. Theriogenology, 49: 1265- 1274.

16. Taneja M K B C Appa Rao S Gangawane S G Zawar and S M Totey (1998). Rapid sexing of bovine preimplantation embryos using PCR: Production of calves with predetermined sex under field conditions. Ind. J. Exp. Biol. 36:1201-1208.

17. Greyling J P C (1988). Certain aspects of reproduction physiology in the boer goat doe $\mathrm{Ph} \mathrm{D}$ Thesis University of Stellenbosch Stellenbosch RSA.

18. Greyling J P C and Van Der Nest M (2000). Synchronization of oestrus 
$\begin{array}{llll}\text { AL-Qadisiya Journal of Vet.Med.Sci. } & \text { Vol./12 } & \text { No./1 }\end{array}$

in goats does affect of progestagen

Small Rum Res 36:201- 207.

19. Hafez B and Hafez E S E (2000). Reproduction in farm animals 7th ed Lippincott Williams and Wilkins A wolter Kluwer Co., Philadelphia U.S.A.

20. Wani N A Wani G M Khan M Z and Salahudin S (2000). Effect of oocyte harvesting technique on in vitro maturation and in vitro fertilization in sheep Small Rum Res 36: 63- 67.

21. Sogorescu E Zamfierescu S Anghel A $\mathrm{H}$ and Dorina N (2010). The influence of new media on the developmental competence of goat and sheep oocytes. Romanian Biotech. Letter, 15 (3): 19- 25.

22. Wang $\mathrm{Z} G \mathrm{Xu} Z \mathrm{Z}$ and $\mathrm{Yu} S \mathrm{D}$ (2007). Effect of oocyte collection techniques and maturation media on in vitro maturation and subsequent embryo development in Boer goat. Czech J. Anim. Sci., 52: 21- 25.

23. Rahman A N M A Abdullah R B and Wan-Khadi Jah W E (2008a). Recovery and grading of goat oocytes with special reference to laparoscopic ovum pick-up technique A review Biotechnol 7 (4): 612- 622.

24. Kharche S D Goel P Jha B K Goel A $\mathrm{K}$ and Jindal S K (2011). Factors influencing in vitro embryo production efficiency caprine oocytes: A review Indian J Anim. Sci., 81 (4): 344- 361.

25. Camargo, L. S. A.; Viana, J. H. M.; Sa, W. F.; Ferreira, A. M.; Ramos A A and Vale Filho V R (2006). Factors influencing in vitro embryo production. Anim. Reprod., 3: 1928.

26. Khatun $M$ Bhuiyan $M$ M Ahmed J Haque A Rahman M B and Shamsudin M (2011). In vitro maturation and fertilization of prepubertal and pubertal black Bengal goat oocytes. J. Vet. Sci., 12 (1): 75- 82.

27. Hoque $S$ A $M$ Kabiraj S K Khandoker M A M Y Mondal A and Tareq K M A (2011). Effect of collection techniques on cumulus oocyte complex (COCs) recovery, in vitro maturation and fertilization of goat oocytes. Afr. J. Biotech., 10(45):9177- 9181.

28. JOERG H ASA M GRAPHODATSKAYA D et al Validating bovine sexed semen samples using quantitative PCR J Anim . Breed. Genet v.121, p.209215, 2004.

29. PARATI K BONGIONI G ALEANDRI $\mathrm{R}$ et al Sex ratio determination in bovine semen: A new approach by quantitative real time PCR. Theriogenology, v.66, p.2202-2209, 2006.

30. PUGLISI R VANNI R GALLI A et al (2006). In vitro fertilisation with frozen-thawed bovine sperm sexed by flow cytometry and validated for accuracy by real-time PCR. Reproduction, v.132, p.519-526.

31. Corson SL, Batzer FR, Alexander NJ, Schlaff S, Otis C. sex selection by sperm separation and insemination. Fertile Steril. 1984; 42:756-760.

32. Breenink FJ, Ericsson RJ. Male sex preselection through sperm isolation. Fertile Steril 1982; 38:493-495. 
$\begin{array}{llll}\text { AL-Qadisiya Journal of Vet.Med.Sci. } & \text { Vol./12 } & \text { No./1 }\end{array}$

\title{
فصل الحيامن الذكرية بالاكباش بواسطة تقنية الالبومين وتجنيس الاجنة المخصبة

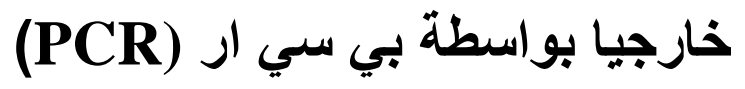

\author{
سجى هادي احسان حمودي التميمي \\ كلية الطب البيطري/جامعة بعداد \\ الخلاصة البطرية
}

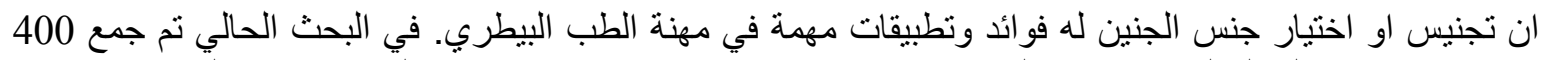

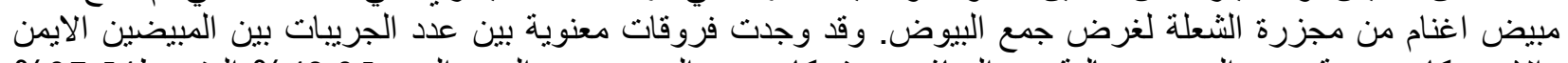

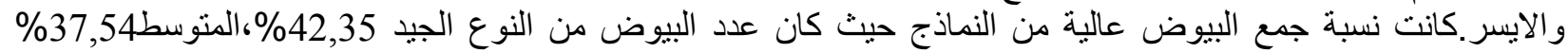

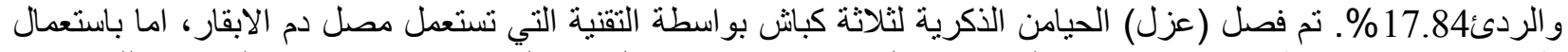

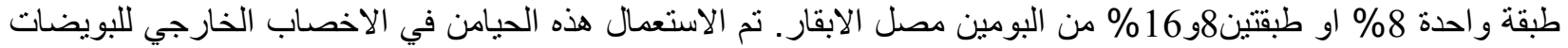

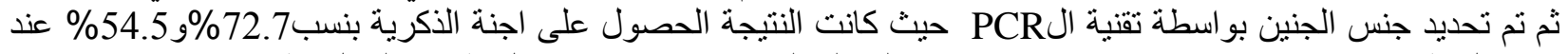

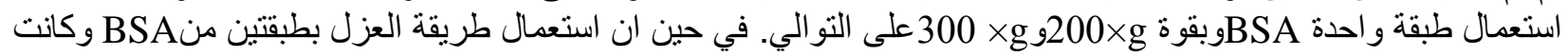

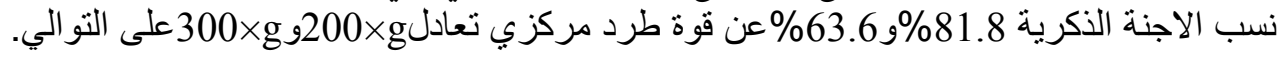

